\title{
Consumer Behavior, Advertisements on Social Networks, and Reliance on the Advertisement Information: Perceptions of Senior High School Student
}

\author{
Kim Edward S. Santos, MBA
}

Wesleyan University, Philippines

kimnyte@gmail.com

\begin{abstract}
One of the critical components in a business's success is an understanding of their consumers' behavior. Consumer behavior can assist businesses in determining the demand for a certain product or service during a particular season. The present study examined the consumer behavior on purchasing, attitude towards advertisements on social networks, and reliance on the information dissemination of advertisement on social media among senior high school students. The study employed a quantitative descriptive technique and surveyed 217 senior high school students from diverse STEM, ABM, HUMSS, and GAS strands enrolled at Wesleyan University-Philippines. It was, then, concluded that they check the provided information of the product/service before they purchase it. Also, they find social networks comfortable, and very important. Further, they rely on social media in checking the products / services that they want to purchase. These social networking sites are increasingly being used for purposes other than personal communication. Social media appears to have endless potential. People rarely go a day without referring to or using social media. Whether used for communicating, learning, or making decisions, social media is here to stay and will continue to have an impact on our society. The researcher recommends the following: (1) product or service companies should always does true advertising to gain the trust of their target customers; (2) students should develop skills on how to determine wrong information from provided advertisements; and (3) further research must be conducted on the awareness of true advertising and digital marketing.
\end{abstract}

Keywords-Consumer, Consumer Behavior, Advertisement, Advertising, Social network.

\section{INTRODUCTION}

One of the critical components in a business's success is an understanding of their consumers' behavior. Consumer behavior can assist businesses in determining the demand for a certain product or service during a particular season. Consumers purchase things to which they are personally engaged and which have been generated through advertisement in audio, video, and text formats (Niazi et al., 2012). Further, a purchasing decision can be thought of as an optimization process in which customers seek out the product or brand that will provide them with the maximum amount of satisfaction (Kumar \& Raju, 2013).

Advertisements on social networks generate a high return when they are directly tied to consumer demand, and advertisers must respect customers' privacy while packaging ads so that they are accepted even if they are viewed as an intrusion (Buami, 2014). Though, utilizing a persistent advertisement for an extended period of time may result in inattention and ignorance toward advertisements and sidebars on web sites and even in the news (Kardan \& Hooman, 2013).
Consumers appeared to be more receptive to social network advertisements when they were provided with entertaining, informative, or sociable information or impressions (Taylor et al., 2011; Saxena \& Khanna, 2013). However, there appears to be a risk that addressing consumer privacy concerns while continuing to target marketing will result in individuals being less susceptible to such advertisements (Tucker, 2014). Thus, when privacy concerns are high, a prevention-oriented approach may increase awareness of personalized adverts' manipulative intent (Kirmani and Zhu 2007).

In light of the aforementioned studies, the researcher examined consumer behavior in the setting of senior high school students in the Philippines as influenced by marketing on social media.

\section{OBJECTIVES OF THE STUDY}

The present study examined the consumer behavior on purchasing, attitude towards advertisements on social networks, and reliance on the information dissemination of advertisement on social media among senior high school students. 


\section{METHODOLOGY}

The present study employed a quantitative descriptive technique, as this is a fundamental way of research that investigates the topic in its present state (Williams, 2007). The study used convenience sampling to survey 217 senior high school students from diverse STEM, ABM, HUMSS, and GAS strands enrolled at Wesleyan UniversityPhilippines. The study employed survey research since it requires data analysis and interpretation (Salaria, 2012). The questionnaire was adapted from one developed by Daroch (2017).

\title{
III. RESULTS AND DISCUSSIONS
}

Table 1. Consumer Behavior on Purchasing

\begin{tabular}{llcc}
\hline \multicolumn{1}{c}{ Statement } & Mean & Verbal Interpretation \\
\hline 1. I normally buy products which I have long known & 3.12 & Agree \\
2. It often happens that sellers talk me into buying things that I don't need & 3.16 & Agree \\
3. I decide what to buy in the shop & 3.49 & Strongly Agree \\
4. I know which information in advertisements is true and which is not & 3.87 & Strongly Agree \\
5. I like to read advertisements and production information & 2.86 & Agree \\
\hline & Average Weighted Mean & $\mathbf{3 . 3 0}$ & Strongly Agree \\
\hline
\end{tabular}

\section{Legend Verbal Interpretation (VI)}

3.25 - 4.00 Strongly Agree (SA)

$2.50-3.24$ Agree (A)

1.75 - 2.49 Disagree (D)

1.00 - 1.74 Strongly Disagree (SD)

Table 1 shows the behavior of senior high school students as consumers on purchasing. The students got an average weighted mean of 3.30, which has a verbal interpretation of "Strongly Agree." They also strongly agreed on Statement 4 "I know which information in advertisements is true and which is not" (Mean = 3.87) and Statement 3 "I decide what to buy in the shop" (Mean = 3.49). The results indicate that the senior high school students check the provided information of the product/service before they purchase it. Customers' purchase intentions are heavily influenced by advertisements. Customers will remember the marketed goods more easily if it is advertised with endorsements. The buyer frequently associates the brand with the celebrity and is able to recall the brand readily (Amandeep, Varshney, \& Aulia, 2017).

Table 2. Attitude towards Advertisements on Social Networks

\begin{tabular}{|c|c|c|}
\hline Statement & Mean & Verbal Interpretation \\
\hline 1. I am very comfortable on social networks. & 3.45 & Strongly Agree \\
\hline $\begin{array}{l}\text { 2. I use social networks a lot to find my chosen } \\
\text { product/service. }\end{array}$ & 3.49 & Strongly Agree \\
\hline 3. Social networks for me are very important. & 3.82 & Strongly Agree \\
\hline 4. I love social networks. & 3.20 & Agree \\
\hline Average Weighted Mean & 3.49 & Strongly Agree \\
\hline
\end{tabular}

\author{
Legend Verbal Interpretation (VI) \\ 3.25 - 4.00 Strongly Agree (SA) \\ $2.50-3.24$ Agree (A) \\ 1.75 - 2.49 Disagree (D) \\ 1.00 - 1.74 Strongly Disagree (SD)
}

Table 2 illustrates the attitude of senior high school students towards social networks. The students got an average weighted mean of 3.49 that has a verbal interpretation of "Strongly Agree". They strongly agreed on Statement 3 "Social networks for me are very important" (Mean = 3.82), Statement 2 "I use social networks a lot to find my chosen product/service." (Mean $=3.49$ ), and Statement 1 "I am very comfortable on social networks." (Mean = 3.45). The data suggests that the use of social networks is another way of checking information 
of product / service through its advertisements. Further, social networks are the more convenient to access information for the students. This supports Gruber (2006) that advertising in online social networks can be successful in light of the fact that in that medium, adverts must compete with user-generated material, which is usually more engaging and appealing to the audience. In other words, people accept adverts on these sites as necessary material in order for the service to remain free.

Table 3. Reliance on the Information of Advertisement on Social Media

\begin{tabular}{llcc}
\hline \multicolumn{1}{c}{ Statement } & Mean & $\begin{array}{c}\text { Verbal } \\
\text { Interpretation }\end{array}$ \\
\hline 1. & \multicolumn{1}{c}{$\begin{array}{c}\text { Social media advertising keeps me up to date about products / services available in } \\
\text { the marketplace }\end{array}$} & 2.72 & Agree \\
2. I will visit a product website after being exposed to an ad on social media. & 3.09 & Agree \\
3. I am a fan of at least one company or brand on social media. & 3.13 & Agree \\
4. I will purchase a product advertised on social media. & 2.76 & Agree \\
5. In my daily activities, I recognize brands as the ones as advertised on social media. & 3.47 & Strongly Agree \\
6. Advertisements on social media provide accurate information about products/services. & 2.47 & Agree \\
\hline & Average Weighted Mean & $\mathbf{2 . 9 4}$ & Agree \\
\hline
\end{tabular}

\section{Legend Verbal Interpretation (VI) \\ $3.25-4.00$ Strongly Agree (SA) \\ $2.50-3.24$ Agree (A) \\ $1.75-2.49$ Disagree (D) \\ 1.00 - 1.74 Strongly Disagree (SD)}

Table 3 illustrates how senior high school students get information of the product or service from its advertisement advertisements on social media. The students got an average weighted mean of 2.94, which has a verbal interpretation of "Agree". They strongly agreed on Statement "In my daily activities, I recognize brands as the ones as advertised on social media." (Mean = 3.47). The results indicate that it is in the daily routine of the students how they can recognize the product they need because of advertisements. MacKenzie and Lutz (1989) stated that Consumers' opinions regarding ads are influenced by the perceived reliability and trustworthiness of the commercial message itself as well as the source supplying it.

\section{CONCLUSIONS AND RECOMMENDATIONS}

The present study examined the consumer behavior on purchasing, attitude towards advertisements on social networks, and reliance on the information dissemination of advertisement on social media among senior high school students. It was, then, concluded that they check the provided information of the product/service before they purchase it. Also, they find social networks comfortable, and very important. Further, they rely on social media in checking the products / services that they want to purchase. These social networking sites are increasingly being used for purposes other than personal communication. Social media appears to have endless potential. People rarely go a day without referring to or using social media. Whether used for communicating, learning, or making decisions, social media is here to stay and will continue to have an impact on our society.

The researcher recommends the following: (1) product or service companies should always does true advertising to gain the trust of their target customers; (2) students should develop skills on how to determine wrong information from provided advertisements; and (3) further research must be conducted on the awareness of true advertising and digital marketing.

\section{REFERENCES}

[1] Amandeep, D., Varshney, S., \& Aulia, S. (2017). The Impact of Advertising on Consumer Purchase Decision with Reference to Consumer Durable Goods in Oman. International Journal of Managerial Studies and Research, 5(12), 11-19.

[2] Buami, E. K. (2014). Social networking site as platform for advertisement: Does it really work. International Journal of ICT and Management, 2(1), 40-47.

[3] Daroch, B. (2017). Consumer's perception towards social media advertising. International Journal of Research in Business Studies, ISSN: 2455-2992, 2(2).

[4] Gruber, F. (2006, July 26). Advertising on Social Networks. Message posted to http://www.imediaconnection.com/content/10585.asp

[5] Kardan, A. A., \& Hooman, M. (2013, April). Targeted advertisement in social networks using recommender 
systems. In 7th International Conference on $e$ Commerce in Developing Countries: with focus on eSecurity (pp. 1-13). IEEE.

[6] Kirmani, A., \& Zhu, R. (2007). Vigilant against manipulation: The effect of regulatory focus on the use of persuasion knowledge. Journal of Marketing Research, 44(4), 688-701.

[7] Kumar, D. P., \& Raju, K. V. (2013). The role of advertising in consumer decision making. IOSR Journal of Business and Management, 14(4), 37-45.

[8] MacKenzie, S. B., \& Lutz, R. J. (1989). An empirical examination of the structural antecedents of attitude toward the ad in an advertising pretesting context. Journal of marketing, 53(2), 48-65.

[9] Niazi, G. S. K., Siddiqui, J., Alishah, B., \& Hunjra, A. I. (2012). Effective advertising and its influence on consumer buying behavior. Information management and business review, 4(3), 114-119.

[10] Salaria, N. (2012). Meaning of the term descriptive survey research method. International journal of transformations in business management, 1(6), 1-7.

[11] Saxena, A., \& Khanna, U. (2013). Advertising on social network sites: A structural equation modelling approach. Vision, 17(1), 17-25.

[12] Taylor, D. G., Lewin, J. E., \& Strutton, D. (2011). Friends, fans, and followers: do ads work on social networks?: how gender and age shape receptivity. Journal of advertising research,51(1), 258-275.

[13] Tucker, C. E. (2014). Social networks, personalized advertising, and privacy controls. Journal of marketing research, 51(5), 546-562.

[14] Williams, C. (2007). Research methods. Journal of Business \& Economics Research (JBER), 5(3). https://doi.org/10.19030/jber.v5i3.2532 